\title{
Stopped-Flow Kinetic Study of Reduction of Ferric Maltol Complex by Ascorbate
}

\author{
Shabana Amin ${ }^{1}$, Shazia Nisar ${ }^{2}$ and S. Arif Kazmi ${ }^{3^{*}}$ \\ ${ }^{1}$ Baxter Corporation, Chicago, IL, USA \\ amin_shabana@hotmail.com \\ ${ }^{2}$ Department of Chemistry, University of Karachi, Karachi 75270, Pakistan \\ shazian@uok.edu.pk \\ ${ }^{3}$ H.E.J. Research Institute of Chemistry, University of Karachi, Karachi 75270, Pakistan \\ kazmi_arif@yahoo.com \\ *Author to whom all correspondence should be addressed. (Email: kazmi_arif@yahoo.com, phone: \\ 923008213565)
}

\begin{abstract}
Stopped-flow kinetic investigation of reduction of $\mathrm{Fe}^{(\mathrm{III})}$-maltol complex is reported. The rates are dependent on $\mathrm{pH}$ in a complex way. On one hand at low $\mathrm{pH}$ there is a predominance of $\mathrm{Fe}^{(\mathrm{III})}$ (maltol) $)_{2}$ which is easier to reduce compared to $\mathrm{Fe}^{(\mathrm{III})}$ (maltol) $)_{3}$ which is more resistant to reduction. On the other hand ascorbate is a stronger reducing agent at higher $\mathrm{pH}$. The rates are also found to be inversely dependent on the concentration of free ligand. These observations are explained by the following rate law:
\end{abstract}

Rate $\left.=\left(\left(\mathrm{k}_{0}+\mathrm{k}_{1}\left[\mathrm{H}^{+}\right]\right) \mathrm{k}_{2}\left[\mathrm{Asc}^{-}\right] /\left(\mathrm{k}_{-1}[\mathrm{HMal}]+\mathrm{k}_{2}\left[\mathrm{Asc}^{-}\right]\right)\right)+\mathrm{k}_{3}\left[\mathrm{Asc}^{-}\right]\right)\left[\mathrm{Fe}^{\prime \prime \prime}(\mathrm{Mal})_{3}\right]$

Here $\mathrm{k}_{1}$ is the rate constant for acid hydrolysis of the $\mathrm{Fe}(\text { maltol })_{3}$ complex to $\mathrm{Fe}(\mathrm{maltol})_{2}$ complex and is directly controlled by $\mathrm{H}^{+}, \mathrm{k}_{0}$ is the rate constant for hydrolysis of the $\mathrm{Fe}$ (maltol) ${ }_{3}$ complex to $\mathrm{Fe}$ (maltol) ${ }_{2}$ complex and is an intrinsic process, $\mathrm{k}$. ${ }_{1}$ is the rate constant of reformation of the tris complex by reaction of the bis complex and the free ligand, $\mathrm{k}_{2}$ is the rate constant for reduction of the bis complex by ascorbate and $k_{3}$ is the rate constant for the reduction of the tris complex by ascorbate.

\section{Indexing terms/Keywords}

Iron(III) maltol complex, saturation kinetics, flavanols

\section{Academic Discipline And Sub-Disciplines}

Physical Sciences

\section{SUBJECT CLASSIFICATION}

Chemistry

\section{TYPE (METHOD/APPROACH)}

Kinetics

\section{INTRODUCTION:}

MALTOL (3-hydroxy-2-Methyl pyran-4-one, CAS No. 118-71-8) is similar to ring C of flavonols which are a class of flavanoids having a 3-hydroxy-2-phenylchromen-4-one backbone [1]. Flavanoids in general and flavanols in particular have strong antioxidant properties [2]. In many cases, the antioxidant properties are attributed to the 3-hydroxy-4-one functionality which makes it a very strong Fe(III) chelator and an inhibitor of Fenton reaction [3]. The Fe(III) chelating property of Maltol (Structures given in figure 1) has characteristics similar to that of many flavanols [4]. Metal chelation involves deprotonation of the 3-hydroxy group and thus $3: 1$ complexes with trivalent metal ions $\left(\mathrm{Fe}^{3+}, \mathrm{Al}^{3+}, \mathrm{Ga}^{2+}\right.$ etc.) and 2:1 complexes with divalent metal ions $\left(\mathrm{Cu}^{2+}, \mathrm{VO}^{2+}, \mathrm{Zn}^{2+}\right.$ etc.) are neutral [5]. Complexes of maltol have been suggested for use as medicinal agents, e.g. Bis Maltol OxoVanadium (BMOV) in treatment of diabetes and as nutritional supplements [6]. It has a very low toxicity profile and has been used in food industry for a long time [7]. However there has been some apprehension about its excessive use because of its possible role in Aluminum neurotoxicity [8].

In view of its potential use as an insulin mimicking agent, the vanadium complex of maltol has been studied for its redox reactivity [9]. It has been suggested that iron-maltol complex is first dissociated and the metal and the ligand are metabolized separately after this dissociation [10]. In this study, we report the kinetics of reduction Fe(III) complex of maltol by ascorbate at different $\mathrm{pH}$. The reactions were carried out at constant temperature and ionic strength while Fe:Maltol ratio, $\mathrm{pH}$ and Ascorbate concentrations were varied. The data is explained in terms of (i) Equilibrium between tris and bis forms of the complex; (ii) Varying reduction rates for the bis and tris complexes at different pH resulting from changing redox potentials of the bis and tris complexes and of ascorbate. 

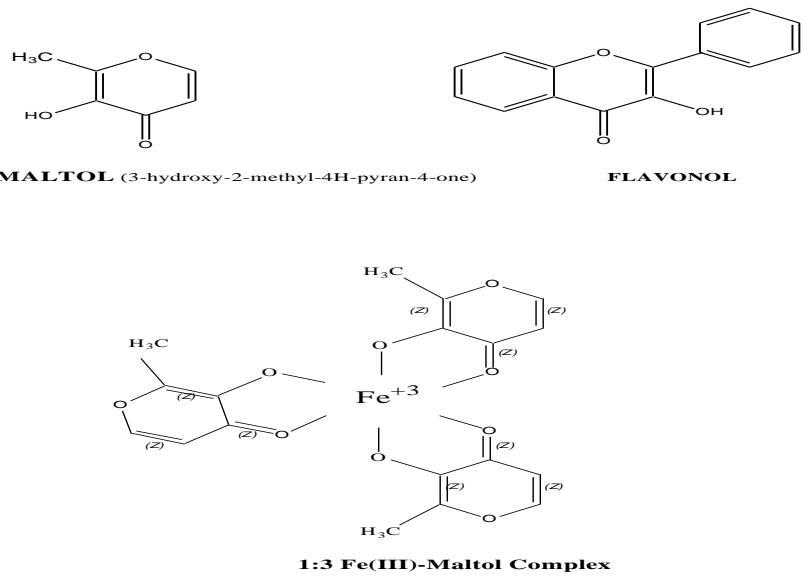

Figure 1

\section{MATERIALS AND METHODS}

$\mathrm{Fe}$ (III) maltol complexes were prepared by mixing appropriate concentrations of Fe(III) and the ligand and making up the volume in a desired buffer (formate or acetate). Solutions were purged with oxygen free Nitrogen before introducing them into storage and drive syringes of the stopped-flow instrument.

Sodium ascorbate was dissolved in the buffer of chosen $\mathrm{pH}$ and the working solutions were prepared from a stock solution whose concentration was estimated by measuring the reducing equivalents present as indicated by its reaction with $\mathrm{K}_{3}\left[\mathrm{Fe}(\mathrm{CN})_{6}\right]$. The buffer solutions used for preparation of stock and working solutions, too, were purged with oxygen free nitrogen.

The stopped-flow reduction experiments were carried out using an Applied Photophysics Rapid Mixing Accessory whose cuvet was placed in a spectrometer. The output of the spectrometer was fed into a computer through an A/D converter. Files of time versus voltages (which were subsequently calibrated to give absorbance values) were created for each reaction [11].

A series of kinetic runs were carried out at a fixed temperature, $\mathrm{pH}$ and ionic strength varying the ascorbate concentrations which were in pseudo first order excess over the $\mathrm{Fe}$ (III)-maltol complexes. In different series the $\mathrm{pH}$ of the reactions was changed.

\section{RESULTS AND DISCUSSION}

Kinetic results are shown in the table 1 and Figures $2 \& 3$. The following trends are noticeable:

*At low pH (3.0-4.5), plots of $\mathrm{k}_{\mathrm{obs}}$ versus [Ascorbate] are indicative of (nearly) saturation kinetics. However, as ascorbate concentration is increased further, there is a small but continuing increase in $\mathrm{k}_{\mathrm{obs}}$.

${ }^{*}$ The observed rate constants decrease as the ratio of maltol concentration to the Fe concentration is increased.

*In the lower $\mathrm{pH}$ range the rates increase with increasing $\left[\mathrm{H}^{+}\right]$, however in the higher $\mathrm{pH}$ range rates increase as the $\mathrm{pH}$ is increased.

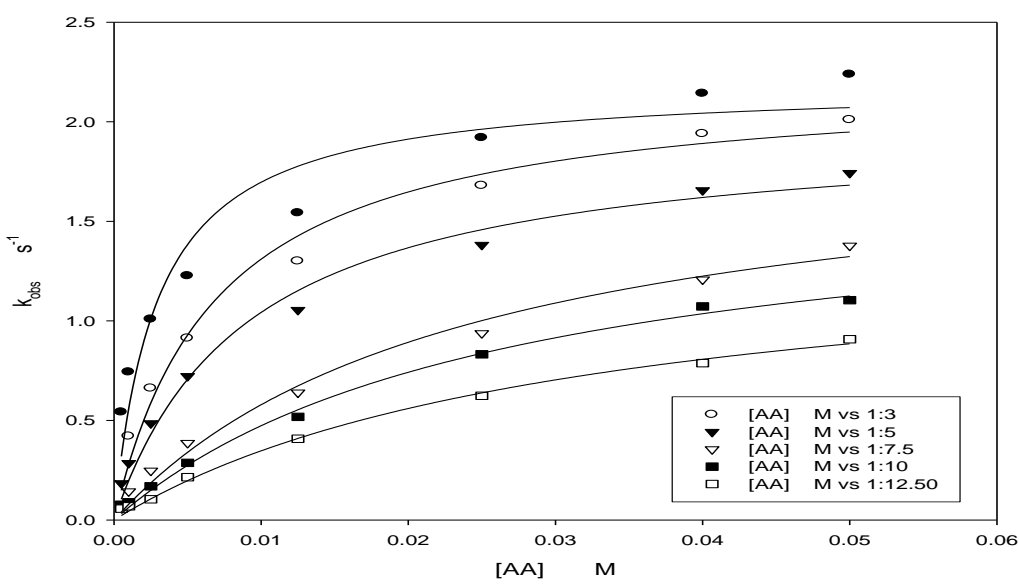

Figure 2: Reduction of Fe(III)-Maltol Complex with Ascorbate at Different Ratios of Maltol 


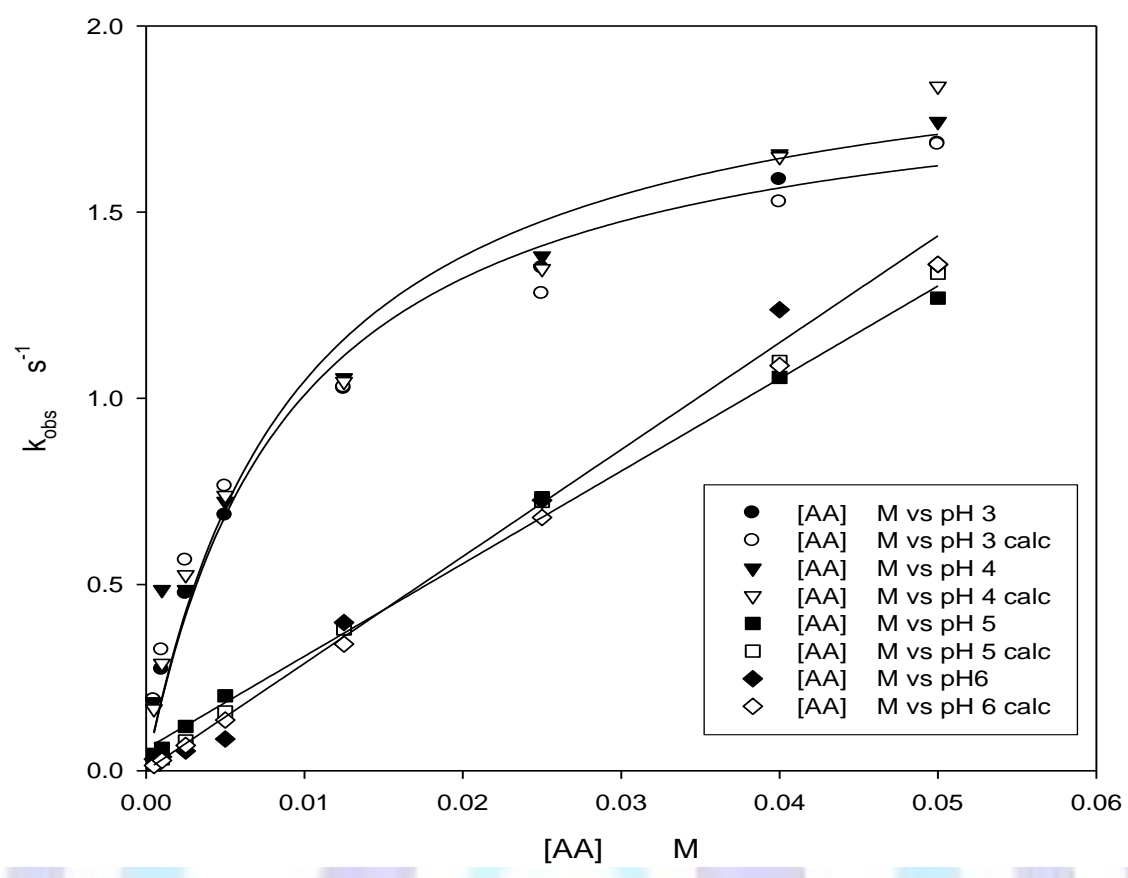

Figure 3: Comparison of the Calculated and Experimental Rate Constants for the Reduction of Fe(III)-Maltol Complex by Ascorbate at Different pH

\section{TABLE 1}

Rate parameters for Reduction of Ferric Maltol Complex by Ascorbate at Different pH

$$
\begin{gathered}
{\left[\mathrm{Fe}(\text { Maltol })_{3}\right]=1.00 \times 10^{-4} \mathrm{M}, \mathrm{T}=25^{\circ} \mathrm{C}, \mathrm{I}=0.35 \mathrm{M}} \\
\mathrm{k}_{1}=2 \times 10^{5} \mathrm{M}^{-1} \mathrm{~s}^{-1} \text { (estimated from graphs) } \\
\mathrm{k}_{-1}=5 \times 10^{4} \mathrm{M}^{-1} \mathrm{~s}^{-1}
\end{gathered}
$$

pH

$$
\times 10^{-3} M^{-1} s^{-1}
$$

$k_{2}$

$M^{-1} s^{-1}$

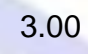

4.00

5.00

6.00
8.2

6.6

1.00 $\mathbf{k}_{3}$

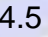

17.8

18.4

27.2

To explain these observations, the following mechanism is suggested:

$$
\begin{aligned}
& \mathrm{Fe}^{\prime \prime \prime \prime}(\mathrm{Mal})_{3}+\mathrm{H}^{+}+2 \mathrm{H}_{2} \mathrm{O} \underset{\mathrm{K}_{-1}}{\underset{\mathrm{k}}{\stackrel{\mathrm{k}_{1}}{\longrightarrow}}} \mathrm{Fe}(\mathrm{Mal})_{2}\left(\mathrm{H}_{2} \mathrm{O}\right)_{2}^{+}+\mathrm{HMal}
\end{aligned}
$$

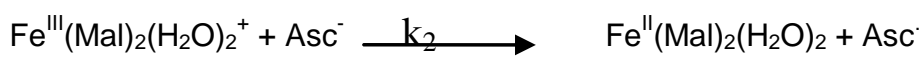

$$
\begin{aligned}
& \mathrm{Fe}^{\prime \prime \prime}(\mathrm{Mal})_{2}\left(\mathrm{H}_{2} \mathrm{O}\right)_{2}{ }^{+}+\mathrm{Asc} \underset{\mathrm{Fast}}{\longrightarrow} \mathrm{Fe}^{\prime \prime}(\mathrm{Mal})_{2}\left(\mathrm{H}_{2} \mathrm{O}\right)_{2}+\mathrm{Asc} \\
& \mathrm{Fe}^{\prime \prime \prime}(\mathrm{Mal})_{3}+\mathrm{Asc}^{-} \longrightarrow \mathrm{Ke}_{3} \longrightarrow(\mathrm{Mal})_{3}+\mathrm{Asc} \\
& \mathrm{Fe}^{\text {III }}(\mathrm{Mal})_{3}+\mathrm{Asc} \stackrel{\text { Fast }}{\longrightarrow} \mathrm{Fe}^{\prime \prime}(\mathrm{Mal})_{3}+\mathrm{Asc}
\end{aligned}
$$


This mechanism will yield a two term rate law. The first term would correspond to the reduction of $\mathrm{Fe}^{\prime \prime \prime}(\mathrm{Mal})_{2}\left(\mathrm{H}_{2} \mathrm{O}\right)_{2}{ }^{+}$. The concentration of this species would increase as the $\mathrm{pH}$ decreases and as a result the observed rate constant will also increase as the $\mathrm{pH}$ is lowered. Another requirement of this mechanism would be that the first term, corresponding to the reduction of $\mathrm{Fe}^{\text {IIII }}(\mathrm{Mal})_{2}\left(\mathrm{H}_{2} \mathrm{O}\right)_{2}{ }^{+}$, would have an inverse dependence upon excess free Maltol. Thus using steady-state approximation for the concentration of $\mathrm{Fe}^{\text {III }}(\mathrm{Mal})_{2}\left(\mathrm{H}_{2} \mathrm{O}\right)_{2}{ }^{+}$, the first term of the overall rate law would be equal to:

$$
\text { Rate }=\left(\mathrm{k}_{1} \mathrm{k}_{2}\left[\mathrm{H}^{+}\right][\mathrm{Asc}]\left(\mathrm{k}_{-1}[\mathrm{HMal}]+\mathrm{k}_{2}\left[\mathrm{Asc}^{-}\right]\right)^{-1}\right)\left[\mathrm{Fe}^{\prime \prime \prime}(\mathrm{Mal})_{3}\right]
$$

Figure 2 shows the effect of [Hmal] on the observed rate constant which decreases as the concentration of free Maltol is increased. If this was the only term in the rate equation, then we would expect at high ascorbate concentrations, the observed rate constants (at any given $\mathrm{pH}$ ) would level off, i.e., increasing ascorbate further would not increase $\mathrm{k}_{\mathrm{obs}}$ any more. This expectation is not met. We suggest that the reason for this is that $\mathrm{Fe}^{\text {III }}(\mathrm{Mal})_{2}\left(\mathrm{H}_{2} \mathrm{O}\right)_{2}{ }^{+}$is not the only species being reduced. Particularly, at higher $\mathrm{pH}, \mathrm{Fe}^{\text {III }}(\mathrm{Mal})_{3}$ is present in larger proportion and at the same time, Ascorbate is a stronger reducing agent. So, the introduction of a second term in the rate law is warranted. This would be:

$$
\text { Rate }=\mathrm{k}_{3}\left[\mathrm{Asc}^{-}\right]\left[\mathrm{Fe}^{\prime \prime \prime}(\mathrm{Mal})_{3}\right]
$$

The overall rate equation, thus, becomes:

$$
\text { Rate }=\left(\left(\mathrm{k}_{1} \mathrm{k}_{2}\left[\mathrm{H}^{+}\right]\left[\mathrm{Asc}^{-}\right]\left(\mathrm{k}_{-1}[\mathrm{HMal}]+\mathrm{k}_{2}\left[\mathrm{Asc}^{-}\right]\right)^{-1}\right)+\mathrm{k}_{3}\left[\mathrm{Asc}^{-}\right]\right)\left[\mathrm{Fe}^{\mathrm{II \prime}}(\mathrm{Mal})_{3}\right]
$$

In a given kinetic run, when $\left[\mathrm{H}^{+}\right]$is kept constant with the use of a buffered medium, a known constant excess of maltol is kept and $\left[\right.$ Asc $\left.{ }^{-}\right]$is in large excess over the $\mathrm{Fe}(\mathrm{III})$ complex to maintain pseudo first order conditions, the rate equation is simplified as:

$$
\begin{aligned}
& \text { Rate }=\mathrm{k}_{\mathrm{obs}}\left[\mathrm{Fe}^{\prime \prime \prime}(\mathrm{Mal})_{3}\right] \text { where, } \\
& \left.\left.\mathrm{k}_{\mathrm{obs}}=\left(\mathrm{k}_{1} \mathrm{k}_{2}\left[\mathrm{H}^{+}\right] /\left(\mathrm{k}_{-1}[\mathrm{HMal}]+\mathrm{k}_{2}\left[\text { Asc }^{-}\right]\right)\right)+\mathrm{k}_{3}\right)[\text { Asc }]\right)
\end{aligned}
$$

Plots of $k_{\text {obs }}$ vs. [Asc] were subjected to non-linear least square analysis after approximation of $k_{1}\left[\mathrm{H}^{+}\right]$and calculating $\mathrm{k}_{-1}$ values from the literature values of the formation constants and our approximate values of $k_{1}$. It is to be understood that both the values of $\mathrm{k}_{2}$ as well as of $\mathrm{k}_{3}$ will change as $\mathrm{pH}$ changes. The values of different rate constants obtained in this manner are given in Table 1.

\section{CONCLUSION}

Since Iron maltol complex has been suggested as a useful agent for Iron deficiency anemia patients who are intolerant of iron $^{12,13}$, it is useful to understand how iron is released from this complex at different $\mathrm{pH}$ (low $\mathrm{pH}$ as in stomach or higher $\mathrm{pH}$ as in small intestine) in presence of ascorbic acid which is usually administered along with iron supplements. Reduction of Ferric-maltol complex is more rapid at lower $\mathrm{pH}$. If the release of free iron is desired to be avoided till the complex reaches the small intestine, it would be better to delay the administration of ascorbic acid for a reasonable interval after the ferric maltol supplement is give.

\section{References:}

[1] K. Zborowski, R. Grybos, L. M. Proniewicz, Vib Spectrosc. 43 (2007) 344-350.

[2] Jong-Deog Kima, L. Liub, W. Guob, M. Meydani, J. Nutr. Biochem. 17 (2006) 165-176.

[3] S. I. Liochev, Met lons Biol Syst. 36 (1999) 1-39.

[4] N. J. Clark, B.N. Willeford Jr., J. Am. Chem. Soc. 79 (1957) 1296-97.

[5] K.H. Thompson, C. Barta, C. Orvig, Chem. Soc. Rev. 35 (2006) 545-556.

[6] K. H. Thompson, C Orvig, J. Inorg. Biochem. 100 (2006) 1925-1935.

[7] E. G. Gralla, R.B. Stebbins, G. L. Coleman, C.S. Delahunt, Toxicol Appl Pharmacol, 15 (1969) 604-13.

[8] R. L. Bertholf, M. M. Herman, J. Savory, R. M. Carpenter, B. C. Sturgill, C. D. Katsetos, S. R. VandenBerg, M. R. Wills, Toxicol. Appl. Pharmacol. 98 (1989) 58-74.

[9] Yan Sun, B. R. James, S. J. Rettig, C. Orvig, Inorg. Chem., 35 (1996) 1667-1673.

[10] M. A. Barrand, B. A. Callingham, P. Dobbin, R.C. Hider, Br. J. Pharmacol. 102 (1991) 723-729.

[11] S. A. Kazmi, A. Lee Shorter, J.V. McArdle, U. Ashiq and R.A. Jamal, Chem. Biodivers. 7 (2010) 656-665

[12] R.S.J. Harvey, D.M. Reffitt, I.a. Doig, J. Meenan, R.D. Ellis, R.P.H. Thompson, J.J. Powell, Aliment. Pharmacol. Ther. 12 (1998) 845-848.

[13] N.C. Andrews, N. Engl. J. Med. 341 (1999) 1986-95. 